\title{
Exploring Programmatic Interoperability: Army Future Force Workshop
}

James D. Smith, II

B. Craig Meyers

September 2005

Integration of Software-Intensive Systems Initiative

Unlimited distribution subject to the copyright.

Technical Note

CMU/SEI-2005-TN-042 
This work is sponsored by the U.S. Department of Defense.

The Software Engineering Institute is a federally funded research and development center sponsored by the U.S. Department of Defense.

Copyright 2005 Carnegie Mellon University.

\section{NO WARRANTY}

THIS CARNEGIE MELLON UNIVERSITY AND SOFTWARE ENGINEERING INSTITUTE MATERIAL IS FURNISHED ON AN "AS-IS" BASIS. CARNEGIE MELLON UNIVERSITY MAKES NO WARRANTIES OF ANY KIND, EITHER EXPRESSED OR IMPLIED, AS TO ANY MATTER INCLUDING, BUT NOT LIMITED TO, WARRANTY OF FITNESS FOR PURPOSE OR MERCHANTABILITY, EXCLUSIVITY, OR RESULTS OBTAINED FROM USE OF THE MATERIAL. CARNEGIE MELLON UNIVERSITY DOES NOT MAKE ANY WARRANTY OF ANY KIND WITH RESPECT TO FREEDOM FROM PATENT, TRADEMARK, OR COPYRIGHT INFRINGEMENT.

Use of any trademarks in this report is not intended in any way to infringe on the rights of the trademark holder.

Internal use. Permission to reproduce this document and to prepare derivative works from this document for internal use is granted, provided the copyright and "No Warranty" statements are included with all reproductions and derivative works.

External use. Requests for permission to reproduce this document or prepare derivative works of this document for external and commercial use should be addressed to the SEI Licensing Agent.

This work was created in the performance of Federal Government Contract Number FA8721-05-C-0003 with Carnegie Mellon University for the operation of the Software Engineering Institute, a federally funded research and development center. The Government of the United States has a royalty-free government-purpose license to use, duplicate, or disclose the work, in whole or in part and in any manner, and to have or permit others to do so, for government purposes pursuant to the copyright license under the clause at 252.227-7013.

For information about purchasing paper copies of SEI reports, please visit the publications portion of our Web site (http://www.sei.cmu.edu/publications/pubweb.html). 


\section{Contents}

Executive Summary ....................................................................................... vii

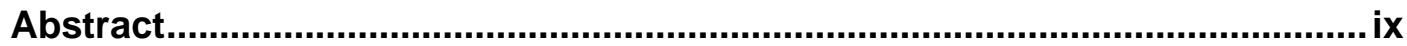

1 Introduction........................................................................................... 1

1.1 Background and Motivation ...................................................... 1

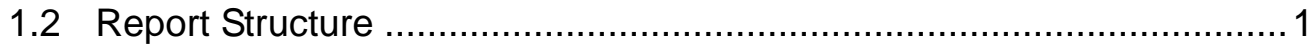

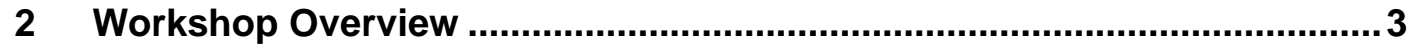

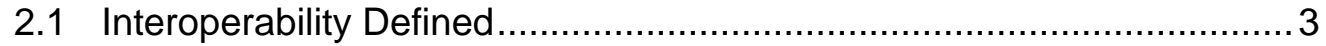

2.2 Workshop Organization .......................................................... 4

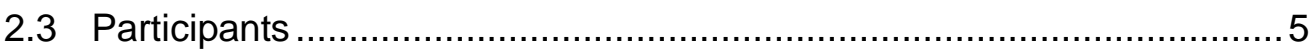

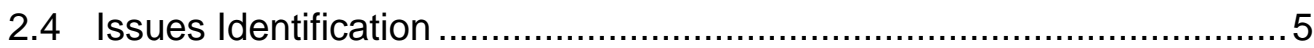

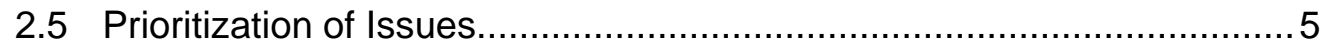

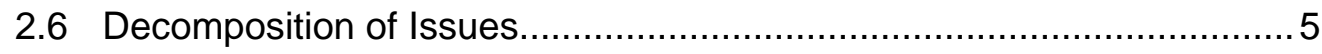

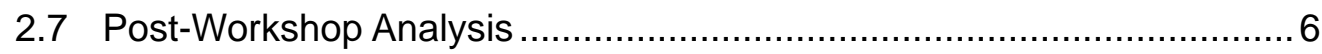

3 Workshop Results ................................................................................ 7

3.1 Issues Identification ................................................................. 7

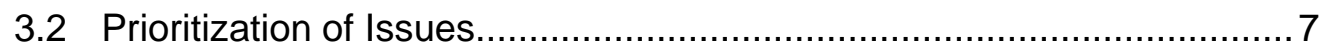

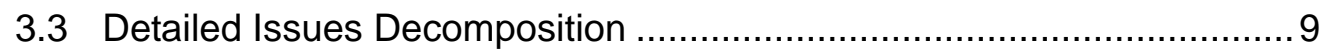

3.3.1 Overview of the Decomposition Process ............................. 9

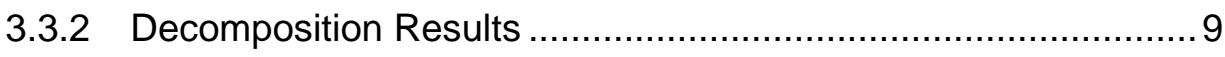

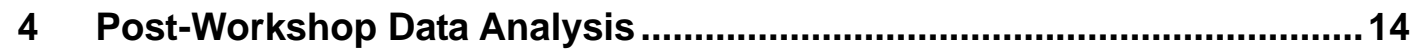

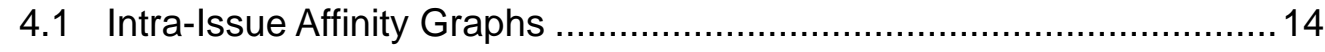

4.2 Cross-Issue Affinity Groupings ................................................. 19

4.3 Interrelations Among Cross-Aspect Affinity Groups ..........................27

4.4 Integration of Post-Workshop Analyses ..........................................2 29

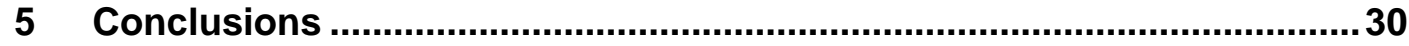

5.1 Operational View Versus Program-Centric View ............................... 30

5.2 Influences of the Current Acquisition Environment ........................... 31 
Appendix A: Participating Organizations ................................................. 33

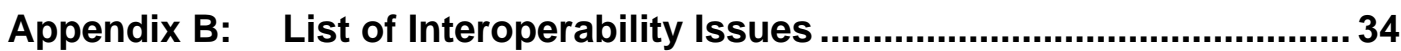

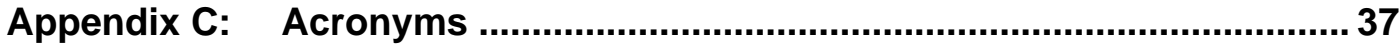

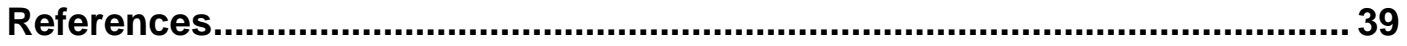




\section{List of Figures}

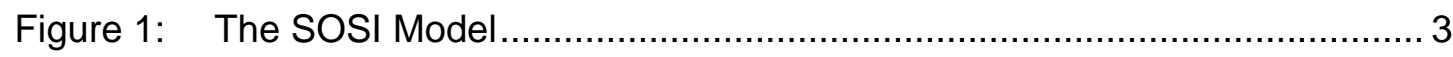

Figure 2: Illustrative Interoperability Issue Decomposition ............................... 9

Figure 3: Issue \#1: The Army is not organized to develop a system of systems. There is a lack of understanding of requirements, money allocation, interaction, and test.

Figure 4: Issue \#2: The procurement versus development lifecycle models causes interoperability problems for when functions implemented.

Figure 5: Issue \#3: A migration plan must be at the appropriate higher level, not based on a bottom-up perspective. Network not the radios, fielding...... 17

Figure 6: Issue \#4: There is a need for a process for measuring operational benefit of proposed interoperability solutions (e.g., cost-benefit analysis)........ 18

Figure 7: Cross-Aspect Interoperability Relationships................................. 28 


\section{List of Tables}

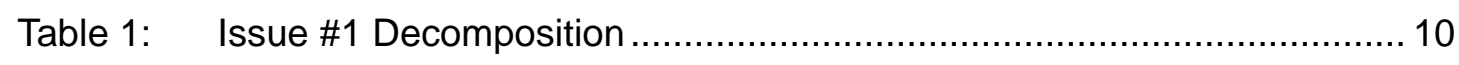

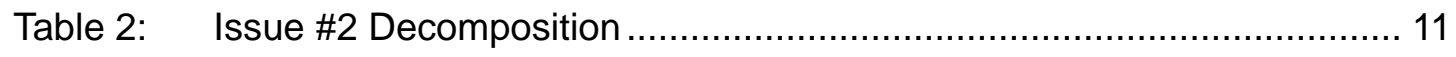

Table 3: $\quad$ Issue \#3 Decomposition ...................................................... 11

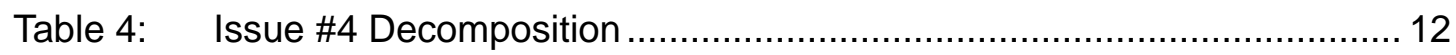




\section{Executive Summary}

The most significant outcome from this workshop was the surfacing of a need for better understanding of how the Army Campaign Plan for the Future Force vision relates to expected approaches for developing an acquisition strategy to achieve that vision. Several aspects of this relationship were explored, and the effects of conflicting influences of organizational, regulatory, and statutory demands were examined.

Specifically, workshop participants identified how individual systems' acquisition strategies need to encompass the total system-of-systems (SoS) perspective, with key decisions informed by cross-system tradeoffs and investment choices spanning multiple programs and appropriations. These principles were contrasted with the "stovepiped" nature of the current acquisition environment, largely driven by the appropriations and requirements processes. This workshop highlighted the clash between the regulatory and statutory framework that guides the acquisition process, and the demands of an effective SoS acquisition strategy. Resolving this conflict lies at the heart of the challenges that confront the Army as it moves towards the Future Force.

This workshop is envisioned as the first of a series of workshops. Where this workshop was structured to identify the broadest possible set of issues_-given the makeup of the participants - subsequent workshops will emphasize either identifying new issues (from areas not covered here), or probing more deeply into a restricted set of issues. 


\section{Abstract}

This report documents the proceedings of the Future Force Workshop held at the Software Engineering Institute on October 13-14, 2004. It describes the background and motivation for the workshop, provides a brief overview of the workshop activities, and highlights the key observations and conclusions obtained through the course of the workshop and postworkshop analyses. In addition, a set of recommended next steps is described. 


\section{Introduction}

\subsection{Background and Motivation}

The Army is undergoing a fundamental transformation in the organization of its combat and support forces. The transformation requires processes to acquire and sustain complex, interoperable systems of systems (SoS). The goals for the Army's transformation are outlined in the Army Campaign Plan (ACP), which describes the goals for the "Future Force." With this background, the Future Force Workshop (FFW) was devised to initiate and facilitate discussion among key Future Force stakeholders (with participation limited, initially, primarily to acquisition and headquarters personnel) on the challenges to achieving and sustaining interoperable SoS. Specifically, this first workshop was designed to

- $\quad$ help the Army identify issues, dependencies, incompatibilities and risks associated with the integration of systems in the context of an interoperable Future Force

- $\quad$ explore use of a workshop as a mechanism for eliciting these issues

In addition, the workshop was intended to help refine the Software Engineering Institute's (SEI) understanding of how the relationships between different "aspects" of interoperability - programmatic, constructive, and operational-affect the ability to acquire, integrate, and field sustainable, interoperable SoS.

\subsection{Report Structure}

Chapter 2 provides an overview of the workshop including structure, participants, and a discussion of how the top issues were identified.

Chapters 3 and 4 presents details of the significant findings from the workshop-including the top issues and their decomposition into different aspects - and the results of the postworkshop data analysis.

Chapter 5 presents some conclusions about the relationship between the present acquisition environment and the demands of SoS development, acquisition, fielding, and sustainment. Finally, some recommendations for future work are presented.

The appendices list the organizations which participated in the workshop (Appendix A), the complete set of interoperability issues identified by the workshop participants (Appendix B), and a list of acronyms (Appendix C). 
Throughout this report, the authors attempted to present the information exactly as it was recorded during the workshop, in order to ensure that we did not change the meaning of the findings. Furthermore, in the absence of any contemporaneous clarifications or additional context, we did not attempt to adduce, after-the-fact, supplementary meaning to the recorded statements. As a result, many of the statements appear somewhat cryptic. 


\section{Workshop Overview}

\subsection{Interoperability Defined}

Some definitions are required before the results from the workshop are described.

Interoperability has traditionally been defined in an operational context (e.g., the ability of systems to exchange information). This definition is too imprecise and incomplete to describe the essential characteristics of interoperability, much less to allow one to reason about possible strategies to achieve-and maintain-interoperability. In the SEI's "System-ofSystems Interoperability” (SOSI) report, Morris and associates discuss how interoperability is not a property of a system in isolation, but is dependent on a particular context [Morris 04]. Specifically, they define interoperability as

The ability of a set of communicating entities to (1) exchange specified state data and (2) operate on that state data according to specified, agreed-upon, operational semantics.

While this definition addresses the issue of context, it doesn't go far enough. The SOSI report further identifies three distinct-but interrelated-aspects of interoperability that, taken together as a whole, provide a richer understanding of what is meant by interoperability. Figure 1, the SOSI model, illustrates these aspects and the relationships between the programmatic, constructive, and operational aspects of interoperability within and across programs [Morris 04, Meyers 05].

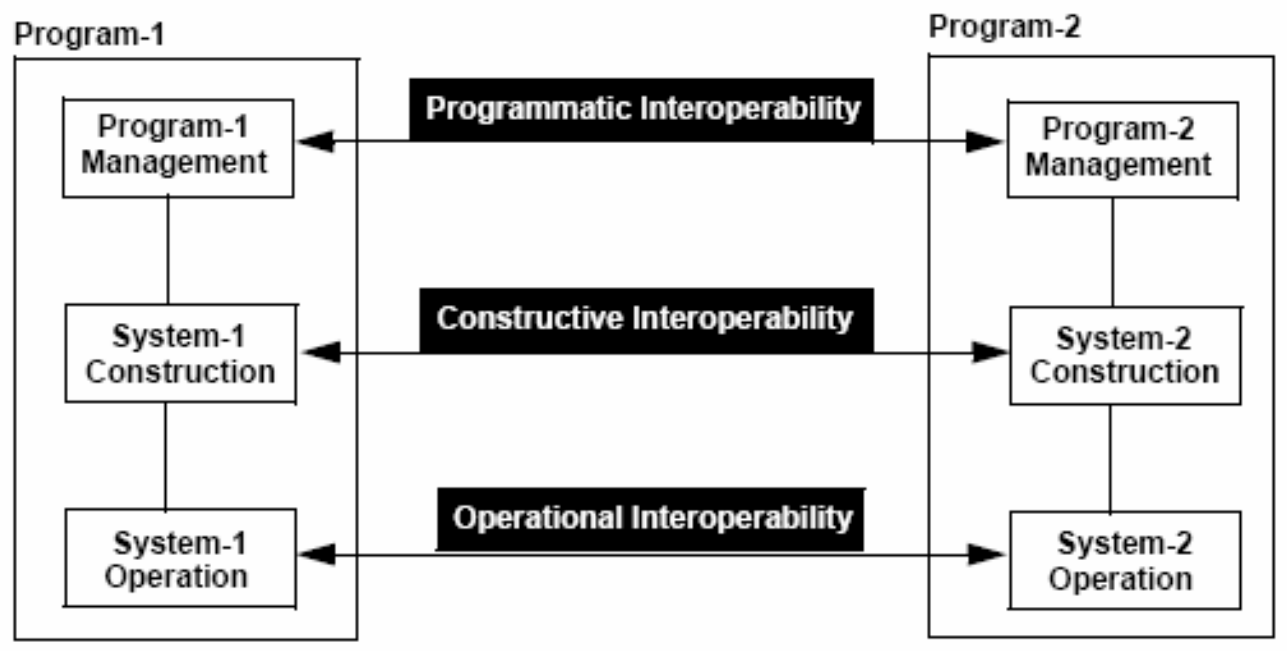

Figure 1: The SOSI Model 
The three interoperability aspects are characterized as follows:

- Operational interoperability is closely aligned with the traditional definition of interoperability: the ability of systems to exchange information, plus the additional notion of compatible (or complementary) operational concepts.

- Constructive interoperability reflects the degree to which the different system design, engineering, and production processes and tools are able to exchange information in an understandable manner.

- Programmatic interoperability expresses the ability of programs to accurately exchange information about the management of the programs involved. This information can run the gamut from budget and schedule information to details on how risks are interpreted.

The emphasis on "aspects" is critical: there is no such thing as a programmatic, constructive, or operational interoperability issue. Instead, there are interoperability issues that have implications or "manifestations" in any or (in most cases) all three interoperability aspects. Whereas traditional treatments of interoperability largely ignore the constructive and programmatic aspects, the participants in the SOSI study concluded that their impact on interoperability is significant. In fact, they concluded that the programmatic interoperability aspects often overwhelm the operational and constructive aspects. For this reason, this workshop focused on eliciting interoperability issues that "bear on" programmatic interoperability, and on understanding the interrelationships between the programmatic, constructive, and operational interoperability aspects of these issues.

For the purposes of this workshop (and the remainder of this report), the SOSI model definitions for interoperability-and the different aspects of interoperability-were used.

\subsection{Workshop Organization}

The workshop took place over two days. The first day started with some "stage setting" and small-group exercises to highlight the shortcomings of a (conventional) program-centric approach to decision-making. The SOSI model was then presented, and a short exercise was conducted to familiarize the participants with the three aspects of interoperability identified by the SOSI model (programmatic, constructive, and operational). The balance of the first day was spent brainstorming issues related to the Future Force transformation. The workshop participants were instructed to be prepared to discuss their individual top two SoS interoperability issues the following day.

The second day began with recording the "top two" issues provided by each workshop participant. As a prelude to a brainstorming session on these issues, and to help stimulate some ideas and discussion, the results of the SOSI IRAD project were briefly presented. The issues were then prioritized by the participants, and the workshop participants were led 
through a brainstorming session to decompose the top four issues into their constituent aspects (i.e., programmatic, constructive, and operational).

\subsection{Participants}

The workshop participants came from various Army organizations, and reflected significant breadth and depth of acquisition experience; additionally, some participants had operational experience. Participants included representatives from Army headquarters, staff elements, Joint and Army acquisition organizations, operational test, research and development, and training and doctrine. The workshop was conducted by personnel from the SEI Integration of Software-Intensive Systems (ISIS) initiative and the Acquisition Support Program (ASP). A complete list of participating organizations is provided in Appendix A.

\subsection{Issues Identification}

After the small group and SOSI exercises on the first day, there was a facilitated brainstorming session to identify some key barriers to achieving SoS interoperability, and an attempt to categorize them into one of four types of issues: general, programmatic, constructive, and operational. A broad set of issues was identified, ranging from "rewards are wrong" to "would like an ORD (operational requirements document) for a system of systems."

At the conclusion of the first day, it was apparent that some additional structure was needed to make the most productive use of the available time. Towards this end, all workshop participants were asked to identify their two most important interoperability issues, and to be prepared to discuss them on the second day. The complete list of identified issues-from both days—is provided in Appendix B.

\subsection{Prioritization of Issues}

Given the relatively large number of issues generated, and the comparatively short time available for the workshop, the decision was made to focus the decomposition and subsequent analyses to a subset of the issues. To narrow the focus to those issues of greatest significance to the Army's Future Force, the workshop participants prioritized the issues using multi-voting. The four most significant issues are discussed in Section 3.

\subsection{Decomposition of Issues}

After the issues were prioritized, the workshop participants dissected the four most significant issues into their constituent programmatic, constructive, and operational interoperability aspects. The results of this decomposition are provided in Section 3. 


\subsection{Post-Workshop Analysis}

After the conclusion of the workshop, the data were analyzed to identify and understand the relations between the interoperability issues identified by the participants—and their programmatic, constructive, and operational aspects. The results of these analyses are presented in Section 4. 


\section{Workshop Results}

The primary purpose of the workshop—-for the Army, certainly—was to "...identify issues, dependencies, incompatibilities, and risks associated with systems integration in the context of the Future Force.” This section will discuss the issues identified by the workshop participants, and their decomposition into programmatic, constructive, and operational interoperability aspects.

\subsection{Issues Identification}

Over the two days of the workshop, the participants identified roughly four dozen issues bearing on the Army's goal of fielding an interoperable Future Force; the complete list is provided in Appendix B. The participants grouped these issues into three fairly broad categories: general issues, programmatic issues, and operational issues. Additionally, there were a number of uncategorized issues (which, as it turns out, was the largest group, reflecting some of the difficulties in applying the SOSI model definitions too literally). Not surprisingly (given the demographics of the participants), most of these issues were related to the acquisition process and, in particular, to the conflicts between the traditional system acquisition processes and the processes believed necessary to successfully acquire, develop, and field an SoS.

\subsection{Prioritization of Issues}

As noted above, most of the issues that dominated the workshop discussions reflected the disconnect between the goals, methods, and awards employed in traditional system acquisition versus the demands of SoS acquisition. This is apparent in how the workshop participants prioritized the issues. The top four issues (in decreasing order of significance) identified were

1. The Army is not organized to develop a system of systems. There is a lack of understanding of requirements, money allocation, interaction, and test. This is a consequence of the fact that, while the Army fields operational capability as integrated units of personnel and equipment in a defined structural relationship, systems are procured individually, in response to separate operational requirements, appropriations, etc. As a result, the organization of the acquisition system does not inherently encourage tradeoffs across systems within an SoS, even though these tradeoffs are necessary to maximize operational effectiveness of the Army as a whole. 
2. The procurement versus development lifecycle models causes interoperability problems when functions are implemented. This issue arises when different systems that must be interoperable are procured separately. Interoperability is frequently defined by sets of standards and interfaces, with systems required to implement these in some common fashion. What can happen is that the organization responsible for procuring system "A" chooses for various reasons (i.e., funding profile, fielding plans) to implement the required standards in a different order than that chosen by the acquiring organization for system "B" (for equally sound reasons). This can result in the two systems being non-interoperable until both have implemented all portions of the specified standards. Since the procurement lifecycles for both systems are driven by their individual requirements and funding lines, the result is that interoperability is delayed for unacceptably long periods of time.

3. A migration plan must be at the appropriate higher level, not based on a bottom-up perspective: Network not the radios, fielding. This issue reflects the disconnect between the present approach to migration planning (i.e., system by system) and the need to plan migration at the force capability level (e.g., Future Force). Unchecked, this issue can lead to a decrease in interoperability if-as is frequently the case - an upgraded system does not provide an exact "form-fitfunction” replacement for its predecessor. One example cited by the participants involved a new system being fielded to operational units that were required to interoperate: as each unit received the new system-in accordance with the fielding plan for the new system - the old system was removed from the unit.

Unfortunately, the new system wasn't fully backwards-compatible with the old system, and the system fielding plan didn't reflect the operational reality that these units would have to deploy and work together, so until all of the units received the new system, there was a net loss of interoperability and a resulting loss of operational effectiveness.

4. There is a need for a process for measuring the operational benefit of proposed interoperability solutions (e.g., cost-benefit analysis). Because so much of the focus in justifying system upgrades and migration of new capability is driven by the individual systems' cost-benefits analysis, there is no agreed-upon mechanism for performing such analyses at the "system-of-systems" level. Or, as pointed out by some of the workshop participants, where such analyses are performed, they are frequently driven by the procurement/fielding/sustainment costs of the proposed upgrade, versus the original system. This generally results in the Analysis of Alternatives (AOA) reflecting a locally optimized solution for an individual program or system, rather than a measure of the operational benefits of the proposed upgrades in the larger perspective. 


\subsection{Detailed Issues Decomposition}

\subsubsection{Overview of the Decomposition Process}

The issues described above were then subjected to further brainstorming to decompose them into their constituent interoperability aspects. That is, the participants identified how each issue was reflected in the interoperability aspects described by the SOSI model: programmatic, constructive, and operational. For example, the first issue relating to the overall Army organization ("The Army is not organized to build a system of systems. There is a lack of understanding of requirements, money allocation, interaction, and test”) is a composite of the individual interoperability aspects, as examined from the programmatic, constructive, and operational perspectives. This is illustrated in Figure 2.

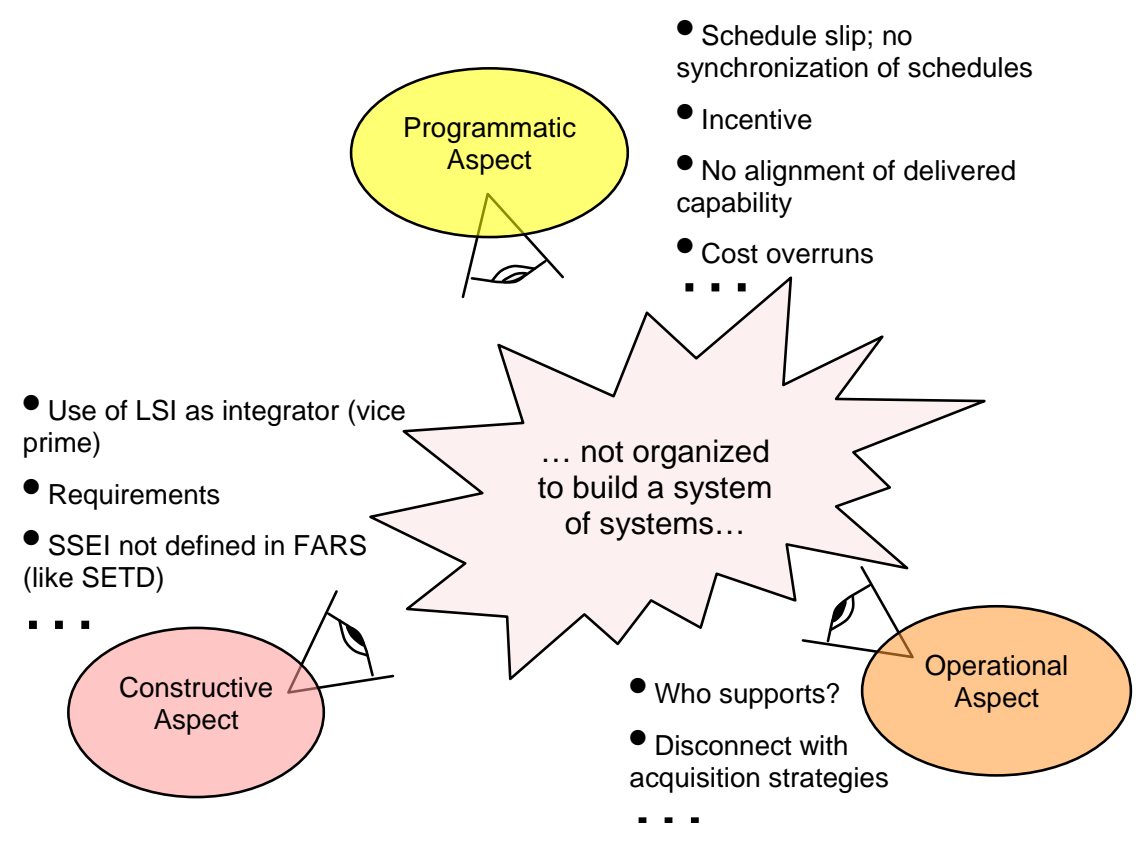

Figure 2: Illustrative Interoperability Issue Decomposition

\subsubsection{Decomposition Results}

Each of the four most-significant issues (as identified and prioritized by the workshop participants) was examined to identify its programmatic, constructive, and operational aspects as described above. The results, as identified by the workshop attendees, are detailed in Tables 1 through 4. 
Table 1: Issue \#1 Decomposition

\begin{tabular}{|c|c|c|}
\hline \multicolumn{3}{|c|}{$\begin{array}{l}\text { Issue \#1: The Army is not organized to develop a system of systems. There is a lack of } \\
\text { understanding of requirements, money allocation, interaction, and test. }\end{array}$} \\
\hline Programmatic & Constructive & Operational \\
\hline $\begin{array}{l}\text { Schedule slip; no } \\
\text { synchronization of schedules }\end{array}$ & $\begin{array}{l}\text { Use of Lead System } \\
\text { Integrator (LSI) as integrator } \\
\text { (vice prime) }\end{array}$ & Who supports? \\
\hline Incentive & Requirements & $\begin{array}{l}\text { Disconnect with acquisition } \\
\text { strategies }\end{array}$ \\
\hline $\begin{array}{l}\text { No alignment of delivered } \\
\text { capability }\end{array}$ & $\begin{array}{l}\text { System-of-systems } \\
\text { Engineering and Integration } \\
\text { (SSEI) not defined in Federal } \\
\text { Acquisition Regulations } \\
\text { (FARS) (like System } \\
\text { Engineering and Technical } \\
\text { Direction (SETD)) }\end{array}$ & $\begin{array}{l}\text { Shift in training focus from } \\
\text { "person" to "SOS readiness" }\end{array}$ \\
\hline Cost overruns & $\begin{array}{l}\text { Specifications don't } \\
\text { collaborate }\end{array}$ & $\begin{array}{l}\text { No integrated approach to } \\
\text { get modularity (like Army } \\
\text { Universal Task List (AUTL)) }\end{array}$ \\
\hline $\begin{array}{l}\text { Interoperability guaranteed to } \\
\text { fail }\end{array}$ & $\begin{array}{l}\text { Contractors not structure/ } \\
\text { incentivized to cooperate }\end{array}$ & \\
\hline $\begin{array}{l}\text { Ineffective resource } \\
\text { management }\end{array}$ & $\begin{array}{l}\text { Capability Maturity Model }{ }^{\circledR} \\
\text { (CMMI }^{\circledR} \text { ) level required }\end{array}$ & \\
\hline $\begin{array}{l}\text { No unity of effort between } \\
\text { acquisition and users }\end{array}$ & $\begin{array}{l}\text { Lack understanding of SOS } \\
\text { requirements }\end{array}$ & \\
\hline Manage \$\$, not engineering & Test, fielding, ??? & \\
\hline $\begin{array}{l}\text { Vision, policies, strategy, } \\
\text { implementation }\end{array}$ & $\begin{array}{l}\text { Proprietary data, intellectual } \\
\text { property }\end{array}$ & \\
\hline No ability to adjust budgets & & \\
\hline $\begin{array}{l}\text { Inability to identify/ resolve } \\
\text { conflict }\end{array}$ & & \\
\hline $\begin{array}{l}\text { Program Initiation Team } \\
\text { (PIT) crew }\end{array}$ & & \\
\hline
\end{tabular}

${ }^{\circledR}$ Capability Maturity Model and CMM are registered in the U.S. Patent and Trademark Office by Carnegie Mellon University. 
Table 2: $\quad$ Issue \#2 Decomposition

Issue \#2: The procurement versus development lifecycle models cause interoperability problems when functions implemented.

\begin{tabular}{|l|l|l|}
\hline \multicolumn{1}{|c|}{ Programmatic } & \multicolumn{1}{|c|}{ Constructive } & \multicolumn{1}{|c|}{ Operational } \\
\hline $\begin{array}{l}\text { Need process for developing an } \\
\text { SOS that emphasizes software }\end{array}$ & $\begin{array}{l}\text { No System Engineering } \\
\text { Management Plan (SEMP) }\end{array}$ & Functions to a block \\
\hline Cost/schedule/performance & $\begin{array}{l}\text { Low price estimates lead to } \\
\text { cost overruns }\end{array}$ & Functional capability \\
\hline $\begin{array}{l}\text { No repeatable process on the } \\
\text { development side }\end{array}$ & $\begin{array}{l}\text { Inadequate Gov't visibility } \\
\text { into contractor SEMP, etc., } \\
\text { means you can't “do" an } \\
\text { SOS }\end{array}$ & \multirow{2}{*}{ Software blocking } \\
\cline { 1 - 2 } Process mismatch & SEMP for SOS & \\
\cline { 2 - 3 } & What to do? & \multicolumn{2}{|l}{} \\
\hline
\end{tabular}

Table 3: Issue \#3 Decomposition

Issue \#3: A migration plan must be at the appropriate higher level, not based on a bottomup perspective. Network not the radios, fielding.

\begin{tabular}{|l|l|l|}
\hline \multicolumn{1}{|c|}{ Programmatic } & \multicolumn{1}{|c|}{ Constructive } & \multicolumn{1}{c|}{ Operational } \\
\hline $\begin{array}{l}\text { Need a vision of what you're } \\
\text { trying to achieve }\end{array}$ & $\begin{array}{l}\text { What engineering? At what } \\
\text { levels? }\end{array}$ & $\begin{array}{l}\text { Need capability to assess } \\
\text { operational implications of } \\
\text { system issues }\end{array}$ \\
\hline $\begin{array}{l}\text { Who does the migration } \\
\text { plan? }\end{array}$ & $\begin{array}{l}\text { Migration plans must } \\
\text { accommodate technology } \\
\text { insertion }\end{array}$ & $\begin{array}{l}\text { Interoperability can be } \\
\text { destroyed by making } \\
\text { "wrong” decisions. }\end{array}$ \\
\hline $\begin{array}{l}\text { There is no migration plan } \\
\text { for the migration plans. }\end{array}$ & $\begin{array}{l}\text { How to ensure consistency } \\
\text { between migration plan and } \\
\text { SEMP? }\end{array}$ & $\begin{array}{l}\text { Lack of coordinated } \\
\text { migration plans can result in } \\
\text { delays in fielding capability }\end{array}$ \\
\hline $\begin{array}{l}\text { Need SOS plan that } \\
\text { encompasses components }\end{array}$ & No SOS migration plan & $\begin{array}{l}\text { Use Clinger-Cohen Act } \\
\text { (CCA) as a “wedge” to force } \\
\text { SOS-level decisions. }\end{array}$ \\
\hline
\end{tabular}




\begin{tabular}{|c|c|c|}
\hline $\begin{array}{l}\text { Need an Army-wide network } \\
\text { migration plan }\end{array}$ & $\begin{array}{l}\text { Visibility into migration } \\
\text { plans for individual systems } \\
\text { which comprise the SOS }\end{array}$ & \\
\hline $\begin{array}{l}\text { Who has authority to } \\
\text { harmonize migration plans? }\end{array}$ & $\begin{array}{l}\text { SOS is held "hostage" to } \\
\text { other systems within the } \\
\text { SOS }\end{array}$ & \\
\hline Not organized correctly & $\begin{array}{l}\text { Consider impacts of } \\
\text { individual system decisions } \\
\text { on entire SOS }\end{array}$ & \\
\hline Who should manage change? & & \\
\hline $\begin{array}{l}\text { How to make cross-system } \\
\text { trades? }\end{array}$ & & \\
\hline $\begin{array}{l}\text { Not managing change: } \\
\text { change is managing us }\end{array}$ & & \\
\hline What types of activities? & & \\
\hline $\begin{array}{l}\text { Bill to fix mistakes impacts } \\
\text { future capability }\end{array}$ & & \\
\hline & $\begin{array}{l}\text { Below-Threshold } \\
\text { Reprogramming (BTR) } \\
\text { thresholds too low to allow } \\
\text { timely investment decisions }\end{array}$ & \\
\hline
\end{tabular}

Table 4: Issue \#4 Decomposition

\begin{tabular}{|c|c|c|}
\hline \multicolumn{3}{|c|}{$\begin{array}{l}\text { Issue \#4: There is a need for a process for measuring operational benefit of propose } \\
\text { interoperability solutions (e.g., cost-benefit analysis). }\end{array}$} \\
\hline Programmatic & Constructive & Operational \\
\hline $\begin{array}{l}\text { AOA not effective at } \\
\text { assessing unit's ability to } \\
\text { perform mission }\end{array}$ & $\begin{array}{l}\text { Program Manager (PM) needs } \\
\text { ability to assess SOS } \\
\text { operational interoperability } \\
\text { implications of proposed } \\
\text { solutions }\end{array}$ & \\
\hline $\begin{array}{l}\text { Cannot do AOA in } \\
\text { "vacuum" }\end{array}$ & $\begin{array}{l}\text { Ability to expose/exploit } \\
\text { existing interoperability } \\
\text { solutions across SOS }\end{array}$ & \\
\hline
\end{tabular}




\begin{tabular}{|l|l|l|}
\hline $\begin{array}{l}\text { Need to perform AOA for } \\
\text { the SOS }\end{array}$ & $\begin{array}{l}\text { PM/Program Executive } \\
\text { Officer (PEO) tenure too short }\end{array}$ & $\begin{array}{l}\text { (Lack of time prevented } \\
\text { identification of operational } \\
\text { aspects for this issue) }\end{array}$ \\
\hline $\begin{array}{l}\text { Need periodic follow-on } \\
\text { AOAs }\end{array}$ & \\
\hline $\begin{array}{l}\text { AOAs only consider "new" } \\
\text { proposed solutions-should } \\
\text { consider existing systems, } \\
\text { too }\end{array}$ & \\
\cline { 1 - 2 } $\begin{array}{l}\text { AOAs too often simply a } \\
\text { "check in a box" as opposed } \\
\text { to something useful }\end{array}$ & \\
\cline { 1 - 2 } $\begin{array}{l}\text { AOAs should be mission- } \\
\text { funded (vice by a PM with a } \\
\text { vested interest in the } \\
\text { outcome) }\end{array}$ & \\
\hline
\end{tabular}

Note: It is possible to argue over the precise classification of specific elements into programmatic, constructive, or operational interoperability aspects. The above tables reflect the decisions of the workshop participants. To the extent that there is debate about the appropriateness of one placement versus another for a given element reflects on the relative inexperience of the participants with the SOSI model, as well as the difficulty in "cleanly" separating complex issues into their constituent components.

To put this data into an understandable context, and allow meaningful conclusions to be drawn, the workshop data was subjected to a variety of affinity grouping and graphing techniques during post-workshop data analysis. This process—and results—are described in more detail in the next section. 


\section{Post-Workshop Data Analysis}

Post-workshop data analysis, performed by the SEI, focused on identifying and understanding the key relationships between the programmatic, constructive, and operational aspects of the top four issues identified by the workshop participants. The purpose for this analysis was twofold:

1. to obtain some insights into what the data-the issues and their respective aspects identified by the workshop participants-revealed as the root causes for these issues

2. to develop a framework for assessing possible solutions.

The following sections describe how the post-workshop analysis was accomplished and highlights some of the immediate results from these analyses.

\subsection{Intra-Issue Affinity Graphs}

The first step in the post-workshop analysis was to examine each of the top four issues in isolation, to see what cross-aspect affinity relationships existed between its constituent components. These were represented in a series of undirected graphs, where the nodes represent the decomposition of the issues into their respective interoperability aspects, and the arcs indicate a relationship. These are shown in Figures 3, 4, 5, and 6.

The graph symbology is explained below:

Schedule slip; no synchronization of schedules 6

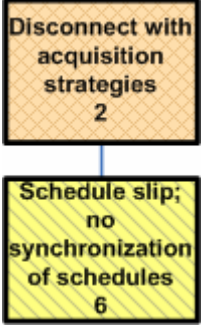

In Figure 3, node 6 is labeled "Schedule slip; no synchronization of schedules." This node is connected to seven other nodes by a set of arcs. The node colors and cross-hatching indicate the particular interoperability aspect: yellow for programmatic, pink for constructive, and orange for operational.

The arcs between node 6 and these other nodes indicate an apparent relationship between these specific aspects of the interoperability issue. For example, the fact that there is a disconnect with acquisition strategies (node 2) seems to contribute to schedule slips.

Note that the arcs are non-directional: the emphasis here is on the existence of relationships, not their causal or semantic interpretations. Additionally, arcs indicate relations between nodes in different aspects: since there is a strong correlation between the nodes within a given aspect, it is believed that the cross-aspect relations provide greater insight into the underlying interoperability issue. 


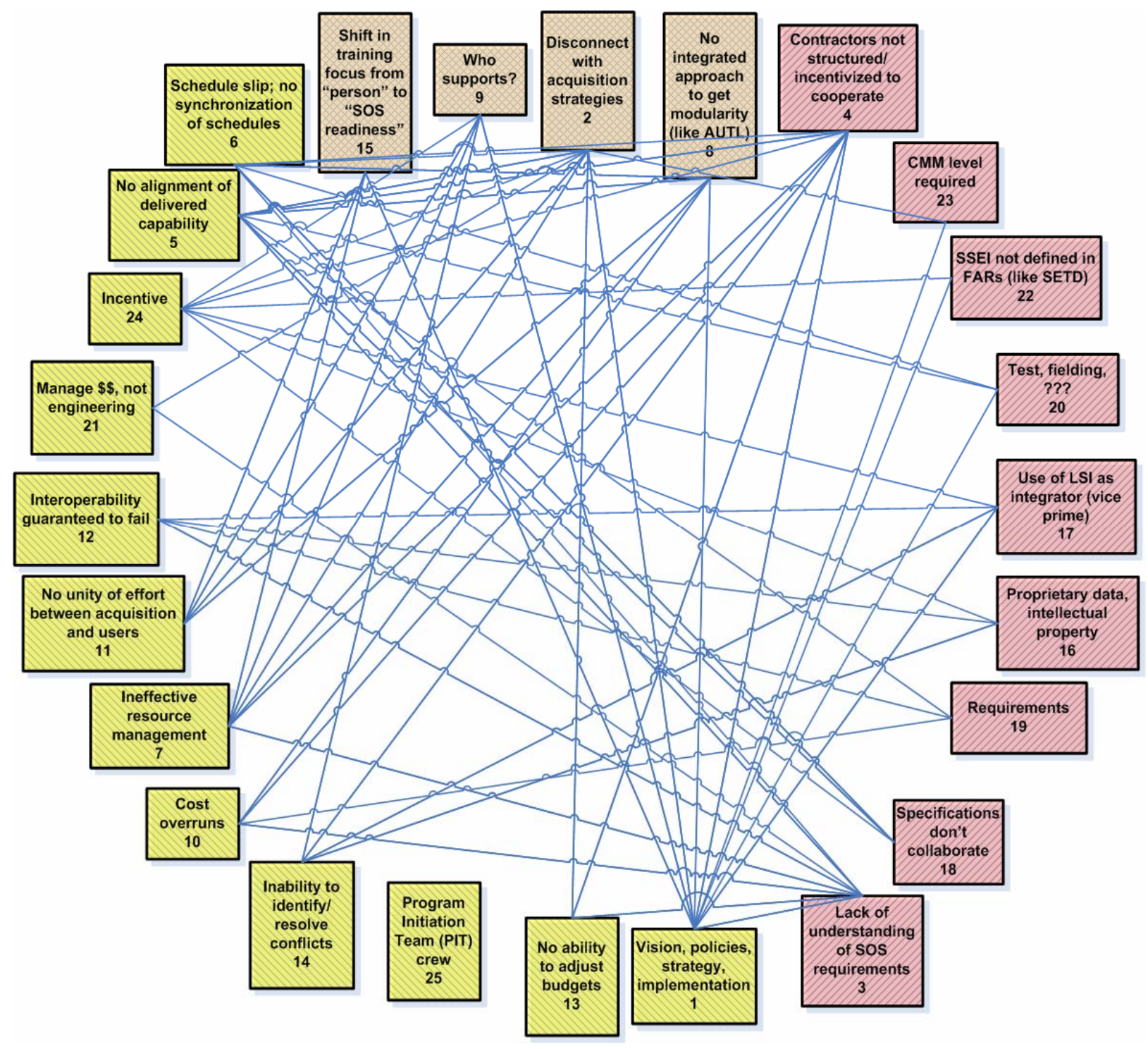

Figure 3: Issue \#1: The Army is not organized to develop a system of systems. There is a lack of understanding of requirements, money allocation, interaction, and test. 


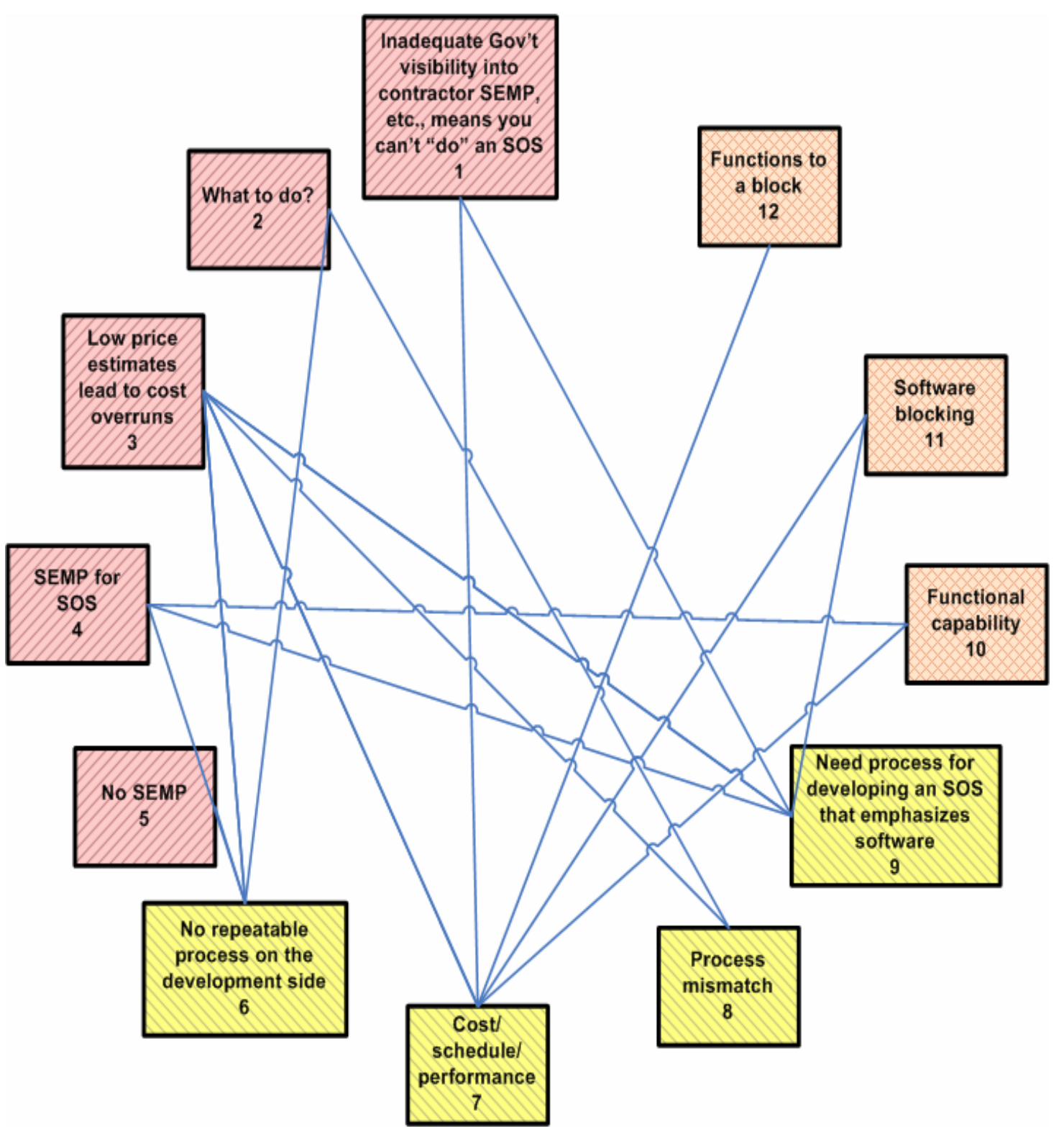

Figure 4: Issue \#2: The procurement versus development lifecycle models causes interoperability problems for when functions implemented. 


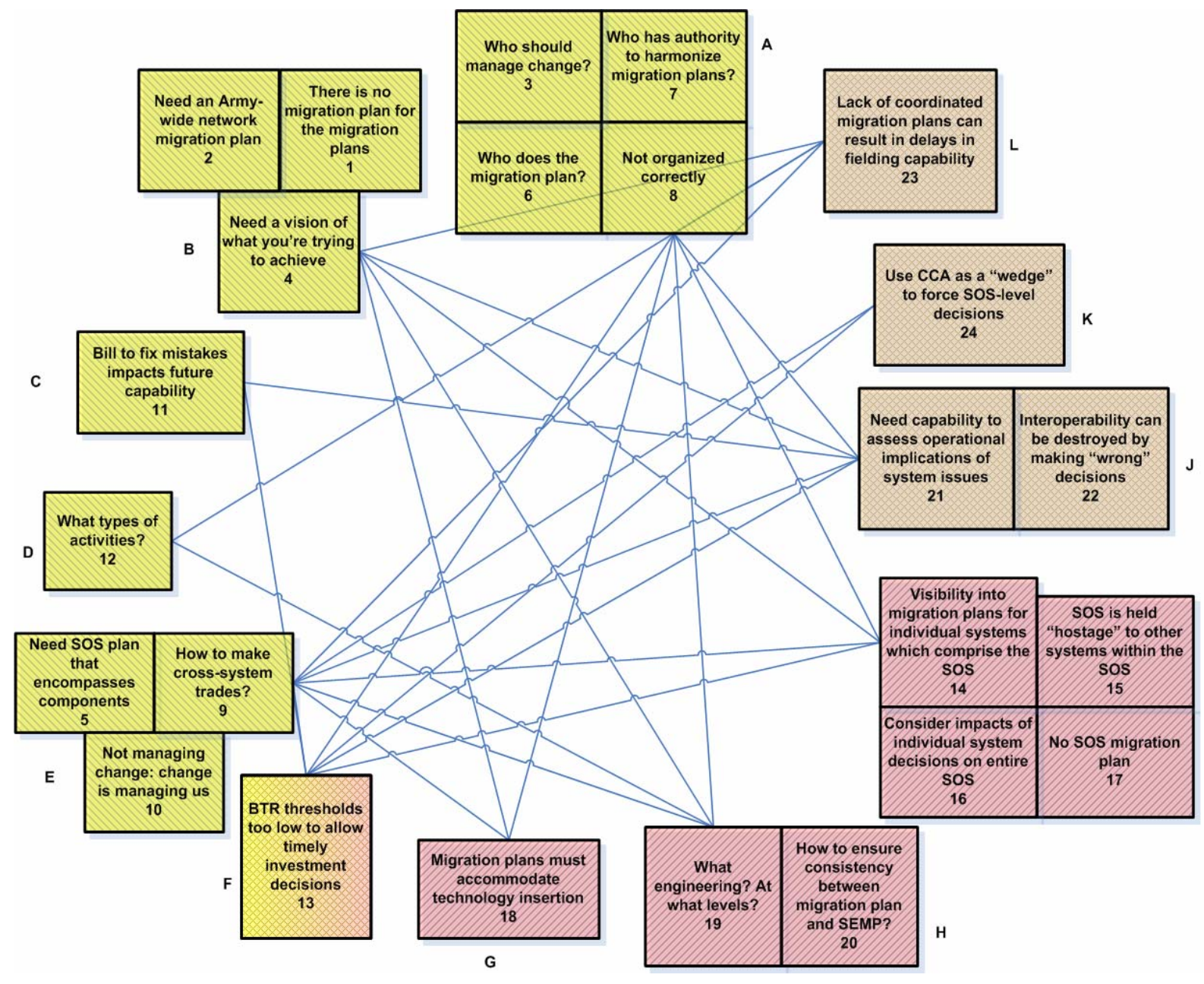

Figure 5: Issue \#3: A migration plan must be at the appropriate higher level, not based on a bottom-up perspective. Network not the radios, fielding. ${ }^{1}$

1 Figure 5 is shown in a "collapsed" form, where related items within each of the three interoperability aspects are grouped together. Using the same format as the other graphs resulted in more than 130 arcs, rendering the graph nearly indecipherable. 


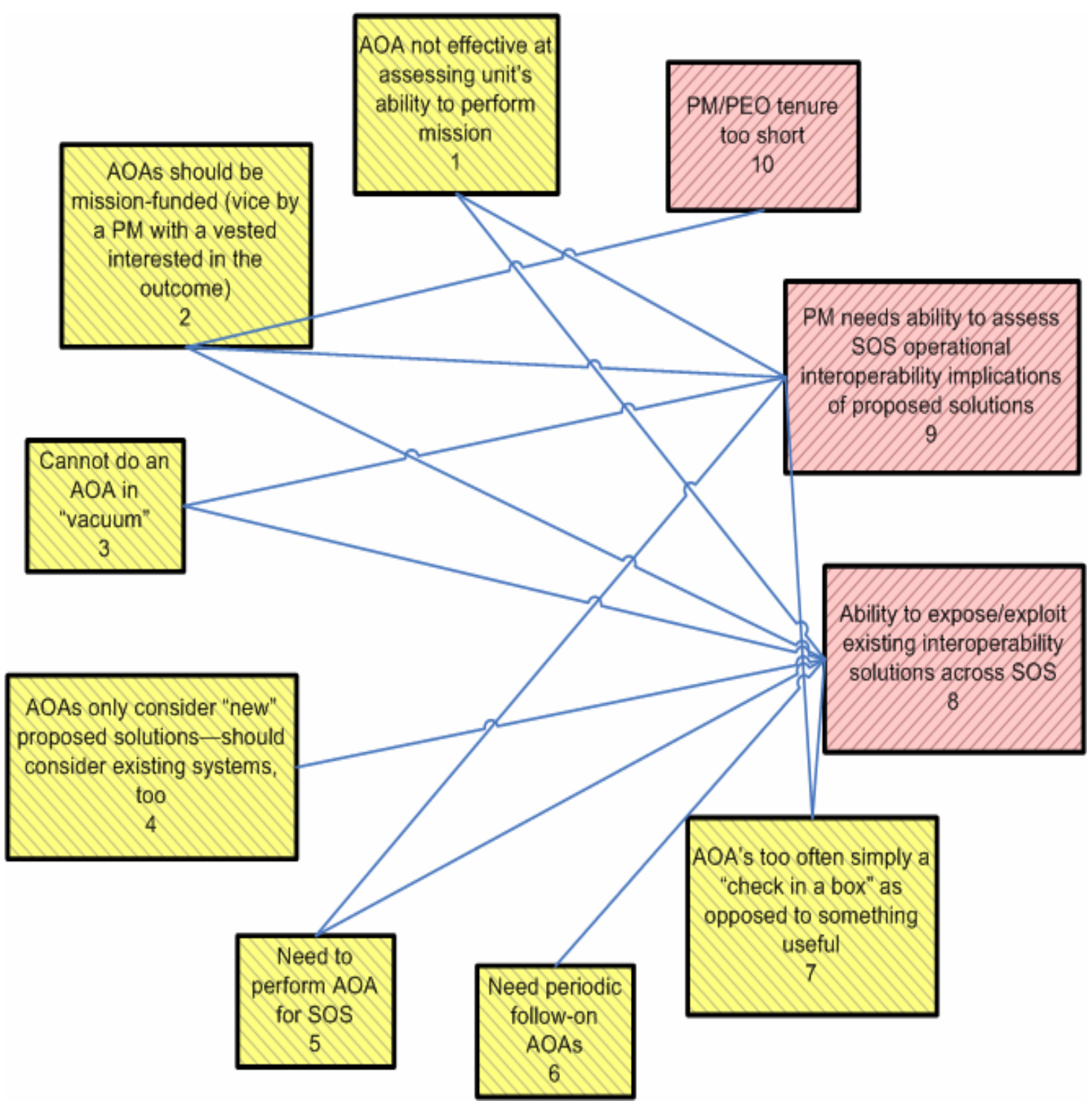

Figure 6: Issue \#4: There is a need for a process for measuring operational benefit of proposed interoperability solutions (e.g., cost-benefit analysis). ${ }^{2}$

While this process revealed the presence of significant coupling between the different interoperability aspects of the top four issues, it didn't afford any particular insights into the larger issues of acquiring, fielding, and sustaining an interoperable Future Force. This indicated the need for additional analysis to attempt to identify patterns in relationships across the top four issues.

2 As noted in Table 4, lack of time precluded identification of any operational interoperability aspects for this issue. 


\subsection{Cross-Issue Affinity Groupings}

Following the intra-issue analysis, the collected issue aspects were examined to discover any affinity groupings — within each aspect—spanning the top four issues. In other words, were there apparent affinity groupings within the programmatic, constructive, and operational aspects across the four issues? The following tables represent these affinity groups. The table title indicates the name given to the affinity group; the first column lists the top four issues, and the second column indicates which aspects - from each issue-were collected into the affinity group.

Programmatic SoS Leadership Issues (p_sos_leadership)

\begin{tabular}{|c|c|}
\hline Issue & Programmatic SoS Leadership Aspect \\
\hline $\begin{array}{l}\# 1 \text { - Not organized to build a system of } \\
\text { systems }\end{array}$ & $\begin{array}{l}\text { Vision, policies, strategy, implementation } \\
\text { Interoperability guaranteed to fail } \\
\text { Program Initiation Team (PIT) crew }\end{array}$ \\
\hline $\begin{array}{l}\text { \#2 - Procurement versus development } \\
\text { lifecycle models }\end{array}$ & \\
\hline $\begin{array}{l}\# 3 \text { - Migration plan must be at the } \\
\text { appropriate higher level }\end{array}$ & $\begin{array}{l}\text { Need an Army-wide network migration plan } \\
\text { Who should manage change? } \\
\text { Not organized correctly } \\
\text { Use CCA as a "wedge" to force SoS-level } \\
\text { decisions }\end{array}$ \\
\hline $\begin{array}{l}\text { \#4 - Need process for measuring operational } \\
\text { benefit }\end{array}$ & \\
\hline
\end{tabular}

Acquisition Strategy Issues (acq_strategy)

\begin{tabular}{|l|l|}
\hline \multicolumn{1}{|c|}{ Issue } & \multicolumn{1}{c|}{ Acquisition Strategy Aspect } \\
\hline $\begin{array}{l}\text { \#1 - Not organized to build a system of } \\
\text { systems }\end{array}$ & \\
\hline $\begin{array}{l}\# 2 \text { - Procurement versus development } \\
\text { lifecycle models }\end{array}$ & $\begin{array}{l}\text { Need a vision of what you're trying to } \\
\text { achieve }\end{array}$ \\
\hline $\begin{array}{l}\text { \#3 - Migration plan must be at the } \\
\text { appropriate higher level }\end{array}$ & \\
\hline
\end{tabular}




\begin{tabular}{|l|l|}
\hline & $\begin{array}{l}\text { Interoperability can be destroyed by making } \\
\text { "wrong” decisions }\end{array}$ \\
\hline $\begin{array}{l}\text { \#4 - Need process for measuring operational } \\
\text { benefit }\end{array}$ & \\
\hline
\end{tabular}

SoS Management Issues (sos_mgmt)

\begin{tabular}{|c|c|}
\hline Issue & SoS Management Aspect \\
\hline $\begin{array}{l}\# 1 \text { - Not organized to build a system of } \\
\text { systems }\end{array}$ & $\begin{array}{l}\text { Incentives } \\
\text { Manage \$\$, not engineering } \\
\text { No unity of effort between acquisition and } \\
\text { users } \\
\text { Inability to identify/resolve conflicts } \\
\text { No ability to adjust budgets } \\
\text { There is no migration plan for migration } \\
\text { plans } \\
\text { Need SoS plan that encompasses components } \\
\text { Who has authority to harmonize migration } \\
\text { plans? }\end{array}$ \\
\hline $\begin{array}{l}\text { \#2 - Procurement versus development } \\
\text { lifecycle models }\end{array}$ & $\begin{array}{l}\text { Need process for developing an SoS that } \\
\text { encompasses software }\end{array}$ \\
\hline $\begin{array}{l}\text { \#3 - Migration plan must be at the } \\
\text { appropriate higher level }\end{array}$ & Who does the migration plan? \\
\hline $\begin{array}{l}\text { \#4 - Need process for measuring operational } \\
\text { benefit }\end{array}$ & $\mathrm{PM} / \mathrm{PEO}$ tenure too short \\
\hline
\end{tabular}


SoS Processes Issues (sos_process)

\begin{tabular}{|l|l|}
\hline \multicolumn{1}{|c|}{ Issue } & \multicolumn{1}{c|}{ SoS Processes Aspect } \\
\hline $\begin{array}{l}\# 1 \text { - Not organized to build a system of } \\
\text { systems }\end{array}$ & \\
\hline $\begin{array}{l}\# 2 \text { - Procurement versus development } \\
\text { lifecycle models }\end{array}$ & Process mismatch \\
\hline $\begin{array}{l}\text { \#3 - Migration plan must be at the } \\
\text { appropriate higher level }\end{array}$ & \\
\hline $\begin{array}{l}\text { \#4 - Need process for measuring operational } \\
\text { benefit }\end{array}$ & \\
\hline
\end{tabular}

SoS Analysis of Alternatives Issues (sos_aoa)

\begin{tabular}{|c|c|}
\hline Issue & SoS Analysis of Alternatives Aspect \\
\hline $\begin{array}{l}\# 1 \text { - Not organized to build a system of } \\
\text { systems }\end{array}$ & \\
\hline $\begin{array}{l}\text { \#2 - Procurement versus development } \\
\text { lifecycle models }\end{array}$ & \\
\hline $\begin{array}{l}\# 3 \text { - Migration plan must be at the } \\
\text { appropriate higher level }\end{array}$ & \\
\hline $\begin{array}{l}\# 4 \text { - Need process for measuring operational } \\
\text { benefit }\end{array}$ & $\begin{array}{l}\text { AOAs too often simply a "check in the box" } \\
\text { as opposed to something useful } \\
\text { Can't do AOA in a vacuum } \\
\text { Need periodic follow-on AOAs } \\
\text { AOAs not effective at assessing unit's ability } \\
\text { to perform mission } \\
\text { Need to perform AOA for the SoS } \\
\text { AOAs only consider "new" proposed } \\
\text { solutions-should consider existing systems, } \\
\text { too } \\
\text { AOAs should be mission-funded (vice by a } \\
\text { PM with a vested interest in the outcome) }\end{array}$ \\
\hline
\end{tabular}


SoS Execution Issues (sos_execution)

\begin{tabular}{|l|l|}
\hline \multicolumn{1}{|c|}{ Issue } & \multicolumn{1}{c|}{ SoS Execution Aspect } \\
\hline $\begin{array}{l}\# 1 \text { - Not organized to build a system of } \\
\text { systems }\end{array}$ & $\begin{array}{l}\text { Schedule slip; no synchronization of schedules } \\
\text { No alignment of delivered capabilities } \\
\text { Ineffective resource management } \\
\text { Cost overruns }\end{array}$ \\
\hline $\begin{array}{l}\text { \#2 - Procurement versus development } \\
\text { lifecycle models }\end{array}$ & $\begin{array}{l}\text { Cost/schedule/performance } \\
\text { No repeatable process on the development side }\end{array}$ \\
\hline $\begin{array}{l}\text { \#3 - Migration plan must be at the } \\
\text { appropriate higher level }\end{array}$ & $\begin{array}{l}\text { Bill to fix mistakes impacts future capability } \\
\text { How to make cross-system trades? }\end{array}$ \\
\hline $\begin{array}{l}\text { \#4 - Need process for measuring } \\
\text { operational benefit }\end{array}$ & \\
\hline
\end{tabular}

System-of-System Engineering Issues (sos_engineering)

\begin{tabular}{|l|l|}
\hline \multicolumn{1}{|c|}{ Issue } & \multicolumn{1}{c|}{ SoS Engineering Aspect } \\
\hline $\begin{array}{l}\# 1 \text { - Not organized to build a system of } \\
\text { systems }\end{array}$ & $\begin{array}{l}\text { Individual system requirements clash } \\
\text { Specifications don't collaborate }\end{array}$ \\
\hline $\begin{array}{l}\text { \#2 - Procurement versus development } \\
\text { lifecycle models }\end{array}$ & $\begin{array}{l}\text { Inadequate Gov't visibility into contractor } \\
\text { SEMP, etc., means you can't “do” an SoS } \\
\text { SEMP for SoS }\end{array}$ \\
\hline $\begin{array}{l}\text { \#3 - Migration plan must be at the } \\
\text { appropriate higher level }\end{array}$ & $\begin{array}{l}\text { No SEMP } \\
\text { Lack of understanding of SoS requirements }\end{array}$ \\
\hline $\begin{array}{l}\text { Wh - Need process for measuring operational engineering? At what levels? } \\
\text { benefit }\end{array}$ & $\begin{array}{l}\text { SOS is held “hostage” to other systems } \\
\text { within the SOS } \\
\text { Consider impacts of individual system } \\
\text { decisions on entire SOS }\end{array}$ \\
\hline $\begin{array}{l}\text { interoperability implications of proposed } \\
\text { solutions }\end{array}$ \\
\hline
\end{tabular}


Contractor Management Issues (contractor_mgmt)

\begin{tabular}{|l|l|}
\hline \multicolumn{1}{|c|}{ Issue } & \multicolumn{1}{|c|}{ Contractor Management Aspect } \\
\hline $\begin{array}{l}\text { \#1 - Not organized to build a system of } \\
\text { systems }\end{array}$ & $\begin{array}{l}\text { Contractors no structure/incentivized to } \\
\text { cooperate } \\
\text { CMM level required }\end{array}$ \\
& Use of LSI as integrator (vice prime) \\
SSEI not defined in FARS (like SETD) \\
$\begin{array}{l}\text { \#2 - Procurement versus development } \\
\text { lifecycle models }\end{array}$ & Proprietary data, intellectual property \\
\hline $\begin{array}{l}\text { \#3 - Migration plan must be at the } \\
\text { appropriate higher level }\end{array}$ & \\
\hline $\begin{array}{l}\text { \#4 - Need process for measuring operational } \\
\text { benefit }\end{array}$ & \\
\hline
\end{tabular}

Constructive SoS Leadership Issues (c_sos_leadership)

\begin{tabular}{|l|l|}
\hline \multicolumn{1}{|c|}{ Issue } & \multicolumn{1}{|c|}{ Constructive SoS Leadership Aspect } \\
\hline $\begin{array}{l}\# 1 \text { - Not organized to build a system of } \\
\text { systems }\end{array}$ & \\
\hline $\begin{array}{l}\text { \#2 - Procurement versus development } \\
\text { lifecycle models }\end{array}$ & What to do? \\
\hline $\begin{array}{l}\text { \#3 - Migration plan must be at the } \\
\text { appropriate higher level }\end{array}$ & $\begin{array}{l}\text { Who has authority to harmonize migration } \\
\text { plans? } \\
\text { What types of activities? }\end{array}$ \\
\hline $\begin{array}{l}\text { \#4 - Need process for measuring operational } \\
\text { benefit }\end{array}$ & \\
\hline
\end{tabular}


Cost Estimating Issues (cost_estimate)

\begin{tabular}{|l|l|}
\hline \multicolumn{1}{|c|}{ Issue } & \multicolumn{1}{c|}{ Cost Estimating Aspect } \\
\hline $\begin{array}{l}\text { \#1 - Not organized to build a system of } \\
\text { systems }\end{array}$ & \\
\hline $\begin{array}{l}\# 2 \text { - Procurement versus development } \\
\text { lifecycle models }\end{array}$ & Low price estimates lead to cost overruns \\
\hline $\begin{array}{l}\text { \#3 - Migration plan must be at the } \\
\text { appropriate higher level }\end{array}$ & \\
\hline $\begin{array}{l}\text { \#4 - Need process for measuring operational } \\
\text { benefit }\end{array}$ & \\
\hline
\end{tabular}

Reuse Issues (reuse)

\begin{tabular}{|l|l|}
\hline \multicolumn{1}{|c|}{ Issue } & \multicolumn{1}{c|}{ Reuse Aspect } \\
\hline $\begin{array}{l}\# 1 \text { - Not organized to build a system of } \\
\text { systems }\end{array}$ & $\begin{array}{l}\text { No integrated approach to get modularity } \\
\text { (like AUTL) }\end{array}$ \\
\hline $\begin{array}{l}\text { \#2 - Procurement versus development } \\
\text { lifecycle models }\end{array}$ & Need SoS plan that encompasses components \\
\hline $\begin{array}{l}\text { \#3 - Migration plan must be at the } \\
\text { appropriate higher level }\end{array}$ & \begin{tabular}{l} 
Ability to expose/exploit existing \\
interoperability solutions across SoS \\
\hline benefit - Need process for measuring operational
\end{tabular} \\
\hline
\end{tabular}

Constructive Evolution Issues (c_evolution)

\begin{tabular}{|l|l|}
\hline \multicolumn{1}{|c|}{ Issue } & \multicolumn{1}{c|}{ Constructive Evolution Aspect } \\
\hline $\begin{array}{l}\# 1 \text { - Not organized to build a system of } \\
\text { systems }\end{array}$ & $\begin{array}{l}\text { \#2 - Procurement versus development } \\
\text { lifecycle models }\end{array}$ \\
\hline $\begin{array}{l}\text { \#3 - Migration plan must be at the } \\
\text { appropriate higher level }\end{array}$ & $\begin{array}{l}\text { Consistency between migration plans and } \\
\text { SEMP } \\
\text { Migration plans must accommodate tech } \\
\text { insertion } \\
\text { No SoS-level migration plan }\end{array}$ \\
\hline
\end{tabular}




\begin{tabular}{|l|l|}
\hline & $\begin{array}{l}\text { Visibility into migration plans for individual } \\
\text { systems which comprise the SoS }\end{array}$ \\
\hline $\begin{array}{l}\text { \#4 - Need process for measuring operational } \\
\text { benefit }\end{array}$ & \\
\hline
\end{tabular}

Force Structure Issues (force_structure)

\begin{tabular}{|l|l|}
\hline \multicolumn{1}{|c|}{ Issue } & \multicolumn{1}{|c|}{ Force Structure Aspect } \\
\hline $\begin{array}{l}\# 1 \text { - Not organized to build a system of } \\
\text { systems }\end{array}$ & Who supports? \\
Disconnect with acquisition strategies \\
\hline $\begin{array}{l}\text { \#2 - Procurement versus development } \\
\text { lifecycle models }\end{array}$ & Functional blocking \\
\hline $\begin{array}{l}\text { \#3 - Migration plan must be at the } \\
\text { appropriate higher level }\end{array}$ & Software blocking \\
\hline $\begin{array}{l}\text { \#4 - Need process for measuring operational } \\
\text { benefit }\end{array}$ & \\
\hline
\end{tabular}

Field Operational Capability Issues (field_ops_capability)

\begin{tabular}{|l|l|}
\hline \multicolumn{1}{|c|}{ Issue } & \multicolumn{1}{|c|}{ Field Operational Capability Aspect } \\
\hline $\begin{array}{l}\# 1 \text { - Not organized to build a system of } \\
\text { systems }\end{array}$ & $\begin{array}{l}\text { Shift in training focus from “person” to “SoS } \\
\text { readiness” }\end{array}$ \\
\hline $\begin{array}{l}\# 2 \text { - Procurement versus development } \\
\text { lifecycle models }\end{array}$ & Functions to a block \\
\hline $\begin{array}{l}\# 3 \text { - Migration plan must be at the } \\
\text { appropriate higher level }\end{array}$ & \\
\hline $\begin{array}{l}\# 4 \text { - Need process for measuring operational } \\
\text { benefit }\end{array}$ & \\
\hline
\end{tabular}


Assess Capabilities Issues (assess_capabilities)

\begin{tabular}{|l|l|}
\hline \multicolumn{1}{|c|}{ Issue } & \multicolumn{1}{c|}{ Assess Capabilities Aspect } \\
\hline $\begin{array}{l}\# 1 \text { - Not organized to build a system of } \\
\text { systems }\end{array}$ & \\
\hline $\begin{array}{l}\# 2 \text { - Procurement versus development } \\
\text { lifecycle models }\end{array}$ & \\
\hline $\begin{array}{l}\# 3 \text { - Migration plan must be at the } \\
\text { appropriate higher level }\end{array}$ & $\begin{array}{l}\text { Need capability to assess operational } \\
\text { implications of system issues }\end{array}$ \\
\hline $\begin{array}{l}\text { \#4 - Need process for measuring operational } \\
\text { benefit }\end{array}$ & \\
\hline
\end{tabular}

Operational Evolution Issues (o_evolution)

\begin{tabular}{|l|l|}
\hline \multicolumn{1}{|c|}{ Issue } & \multicolumn{1}{c|}{ Operational Evolution Aspect } \\
\hline $\begin{array}{l}\# 1 \text { - Not organized to build a system of } \\
\text { systems }\end{array}$ & \\
\hline $\begin{array}{l}\# 2 \text { - Procurement versus development } \\
\text { lifecycle models }\end{array}$ & $\begin{array}{l}\text { Not managing change: change is managing } \\
\text { us } \\
\text { appropriate higher level }\end{array}$ \\
\hline $\begin{array}{l}\text { \#4 - Need process for measuring operational } \\
\text { benefit }\end{array}$ & \begin{tabular}{l} 
result in delays in fielding capability \\
\hline
\end{tabular} \\
\hline
\end{tabular}

Similar to the previous analysis stage, this process revealed some additional insights into the relationships between the various interoperability aspects across the top four issues, but failed to bring out the higher level programmatic issues. However, further reflection leads to the realization that these tables can be organized into three broad categories: programmatic, constructive, and organizational. These cross-issue intra-aspect groupings and their natural division into programmatic, constructive, and operational aspects suggest a final analysis step. 


\subsection{Interrelations Among Cross-Aspect Affinity Groups}

A review of the cross-issue groupings and contemporaneous notes from the workshop showed relationships between groupings within each of the three interoperability aspects, as well as relationships between groupings cutting across the aspects. Furthermore, there appeared to be different degrees of coupling ("stronger" or "weaker"), as well as some sense of possible causality. The cross-cutting relationships-representing "touch points" between the programmatic, constructive, and operational aspects-were identified ("cross-aspect" relationships), and a "critical chain” of relationships was identified. These are shown in Figure 7.

This diagram (Figure 7) requires some explanation:

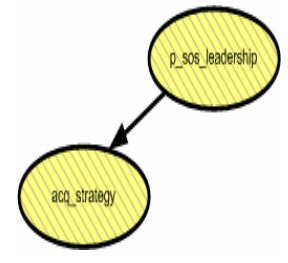

The solid arrow from $\boldsymbol{p} \_$sos_leadership to acq_strategy indicates a stronger coupling from the former to the latter. This implies that the activities and responsibilities attendant in $\boldsymbol{a c q}_{\mathbf{c}}$ strategy are in response to, among other sources, direction from activities resident in p_sos_leadership. The solid arrow denotes the strong relation, as well as its causal nature. (Note that the relation is not strictly one-way; the arrow indicates the "dominant" direction of the relation.)

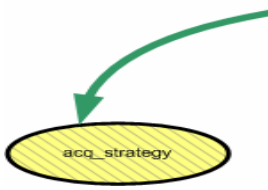

The thicker green arrow into $\mathbf{a c q} \_$strategy represents a cross-cutting relation from a group in another aspect (in this case, operational interoperability). Similarly, the bi-directional green arrow between sos_mgmt and contractor_mgmt indicates a dual relation between these groupings that spans the boundary separating programmatic and constructive interoperability. The dual relation implies that the activities and responsibilities in both groups are in response to, or informed by, the other.

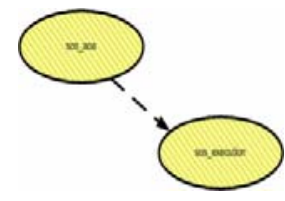

The dashed line from sos_aoa and sos_execution indicates a weaker coupling between these two groups (that is, weaker than the degree of coupling indicated by a solid line).

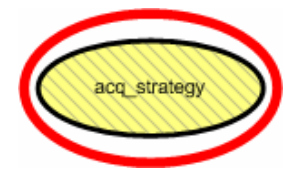

acq_strategy, sos_mgmt, and contractor_mgmt are decorated with red ellipses: these indicate that these groups are part of the critical chain of relations that are necessary for success in fielding the Future Force.

A key point to remember when looking at these diagrams is that they represent what the workshop participants described as necessary for a successful SoS implementation. How they described this was largely through enumerating the shortfalls with the current processes and acquisition framework (e.g., regulations, laws, etc.). Their issues defined the problems; conversely, things outside of the issues represent what is needed. The significance of this will be explained in the following sections. 


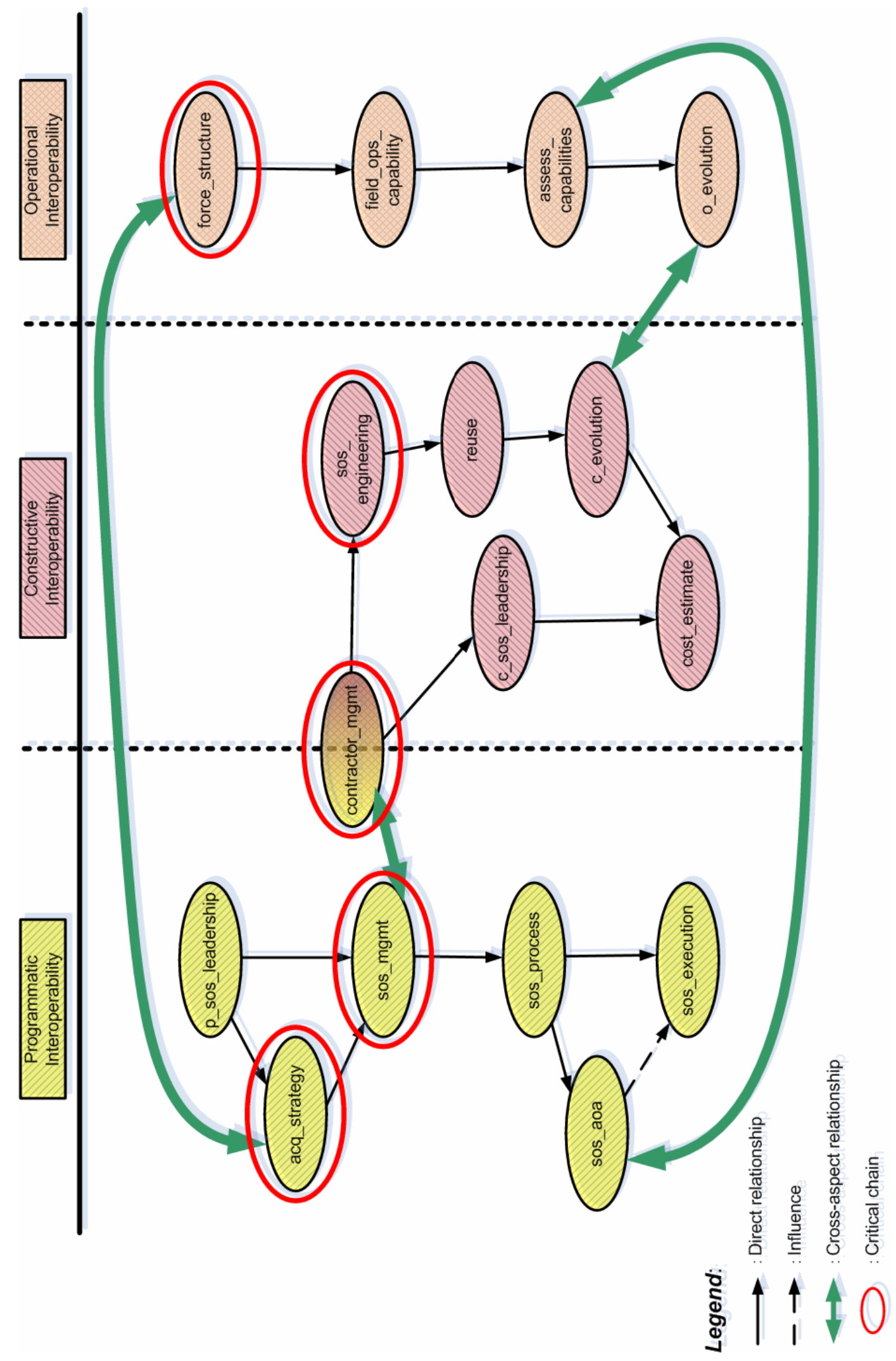

Figure 7: Cross-Aspect Interoperability Relationships 


\subsection{Integration of Post-Workshop Analyses}

It was only after completing all of the aforementioned analyses that an articulable "theme" began to emerge. This theme, which underlies many of the conclusions, was the necessity of a strong cross-aspect coupling between key affinity groups (the so-called "touch points" mentioned earlier). This is shown in Figure 7 by the solid green arrows. In looking at this graph, a few points stand out:

1. A need exists for a linkage between the desired force structure (and attendant operational concepts) and the associated acquisition strategy required to bring this into being. The existence of this touch point between the operational and programmatic interoperability aspects means that the processes, concerns, issues, and so forth, in one area (i.e., "force_structure") must be informed by, and compatible with, their corresponding equivalents in the other area (i.e., “acq_strategy”).

2. Contractor management - traditionally viewed as more of a programmatic concern-is actually both a programmatic and a constructive interoperability concern. The structure of the contractual relationships between the acquirer(s) and developer(s) in an SoS context influences every aspect of the eventual SoS. For example, if the SoS requires close collaboration between developers of different components for the success of the SoS, inappropriate contractual language could actually preclude the sharing of critical intellectual property between developers and lead to the failure of the SoS (or at least a significant loss in anticipated capability, operational utility, etc.).

3. The touch points between the programmatic analysis of alternatives ("sos_aoa") and the assessment of operational capabilities of the SoS (“assess_capabilities”) indicates that individual programs’ analysis of alternatives need to be done in the context of the SoS. The "optimum" choice for a system in isolation will most likely not be the best-from an SoS perspective- when that system is placed into the broader context.

4. Similarly, the constructive and operational aspects of system evolution (indicated by the “evolution” groups under the constructive and operational interoperability aspects) need to be consistent: evolution of a system must be undertaken in the context of the evolving SoS.

The next section will highlight the conclusions drawn from the results of the workshop and post-workshop data analysis, and will make some recommendations about possible "next steps.” 


\section{Conclusions}

The workshop participants identified four key issues related to the acquisition of the Army Future Force. The issues related to

1. the need for a required organizational approach to an SoS acquisition

2. disconnects between the development and procurement lifecycle models

3. the need to address migration plans in the context of an SoS

4. understanding operational benefits at the SoS level

All of these issues stress the contrast between the perspectives of an individual program, acting with a fairly high degree of autonomy, versus that of a PMO executing in the context of a system-of-systems. Two fundamental mechanisms give rise to these issues:

1. an asymmetry between the operational view (in terms of a system of systems) and the program-centric view (of a specific system); reinforced by

2. influences of the current acquisition environment

\subsection{Operational View Versus Program-Centric View}

The workshop participants repeatedly highlighted issues resulting from a disconnect between the way capabilities are implemented operationally, as collections of systems of systems, and the manner in which they are procured, developed, and fielded: as individual systems. This results in

1. issues related to the development, procurement, and fielding of a software-intensive system (represented by a vertical "slice” through a single program in the SOSI model).

This inward focus, or "PMO-centric" view, reflects the traditional program management view of "their" system as the center of the universe.

2. issues arising from the disconnect between the goals, methods, and rewards that have been developed for traditional (i.e., "stovepiped") system procurement and the realities of an SoS approach (represented in the SOSI model by the horizontal linkages between individual programs). This reflects an "SoS-centric" perspective, where systems exist in the context of an SoS.

An example of issues that fall into the first category includes observations like "how you buy a truck is different from how you deliver software" and "proliferation of requirements." Examples of the second category include "acquisition process is not defined for an SoS" and "rewards are wrong." Examining these two broad categories, in turn, reveals additional groupings that reflect the SOSI model's programmatic, constructive, and operational aspects. 


\subsection{Influences of the Current Acquisition Environment}

A recurring theme from the workshop is the perception that the lack of flexibility in the existing regulatory and statutory framework makes it impossible to "do the right thing" for an SoS acquisition. Specifically, the existing framework is strongly oriented towards a programcentric view (e.g., funds are appropriated for specific programs, program execution is at the individual program level, etc.) versus an SoS view. This orientation exists for a number of reasons, not the least of which is the fact that system development, acquisition, and fielding has "always" been done that way. This has resulted in the creation of a "safe harbor" mentality within the acquisition community: program managers (and developers, etc.) have always been able to fall back on the "satisfying the ORD (or contract specifications, etc.)" defense. While it used to be true that "nobody ever got fired for following DoD 5000.2," the emphasis on SoS means that the acquisition community is finding it increasingly difficult to seek refuge in traditional definitions of success. In other words, doing what you've always done isn’t “good enough” for a system-of-systems.

\subsection{Next Steps}

The preceding suggests that a larger perspective is needed. An overarching principle emerges: Program management organizations need to execute in a manner that is consistent with the larger system-of-systems view. Achieving this goal requires

- a vision, not just of the SoS, but of how programs must work together to achieve that vision, including an explicit linkage between the operational architecture (as reflected by evolving force concepts, doctrine, etc.) and the acquisition, development, and fielding of programs within the SoS

- systems engineering at the SoS level—with corresponding linkages to the relevant systems acquisition efforts (including program office and contract management) - to ensure that individual systems provide the operational capabilities needed and "fit" within the larger SoS

The execution of a PMO must be consistent both with an established vision, as well the system engineering approach intended to achieve that vision.

These problems don't result from any lack of vision: vision statements abound! We have observed, however, that there is a lack of system engineering at the SoS level (that encompasses the aforementioned goals) to translate these high-level visions into actionable plans. This suggests several possible courses of action:

- Articulate and assess the role of a system engineering process specifically focused on SoS acquisition and development. In particular, this process must address the context in which the system engineering takes place, and include, for example, funding and issues of control. While there has been progress in the requirements perspective (e.g., JCIDS), there seems to be no corresponding progress in the construction (and lifecycle management) of the systems. 
- Examine the constraints—both real and perceived — to SoS acquisition and development arising from the existing statutory and regulatory considerations, and explore mitigation strategies that don't require specific regulatory and legislative relief.

- Assess the role of current acquisition approaches with an approach that requires interactions among processes to acquire an SoS. It is through an assessment process that one may identify variances in the approaches, and begin to correct them.

In summary, there are several issues arising from the friction between the demands of acquiring and fielding individual programs and doing so in the context of an SoS. The existing acquisition regulatory and statutory framework (and, indeed, the entire history of weapon system acquisition and fielding) emphasizes the individual system over the SoS. Still, there is a burgeoning awareness that the key to future success lies in the identification and adoption of effective practices for managing the complexities inherent in a system-ofsystems world. 


\section{Appendix A: Participating Organizations}

Participants in the October 2004 Future Force Workshop included representatives from the following organizations:

- Office of the Assistant Secretary of the Army for Acquisition, Logistics, and Technology (ASA/ALT)

- Army Test and Evaluation Command (ATEC)

- U.S. Army's Communications - Electronics Research, Development and Engineering Center (CERDEC)

- Office of the Deputy Chief of Staff for Operations (G-3)

- Office of the Deputy Chief of Staff for Command, Control, Communications, and Computers (G-6)

- Office of the Deputy Chief of Staff for Force Structure, Resources, and Assessment (G-8)

- Joint Tactical Radio System (JTRS) Joint Program Office

- Program Executive Officer for Aviation (PEO AVN)

- Program Executive Officer Simulation, Training, and Instrumentation (PEO-STRI)

- $\quad$ Training and Doctrine Command (TRADOC) Program Integration Office (TPIO)

- TRADOC

- Software Engineering Institute (SEI), Carnegie Mellon University 


\section{Appendix B: List of Interoperability Issues}

\section{General}

- Lack of a baseline-if I don’t know what capability I have today, how will I know what I need? No place where you can go

- No consistent function def of what systems are doing. What capability does this block have? This block?

- The problem is we try to hardwire sys for a force structure. But the force structure will change before the system is fielded..... The only way to go is modularity.

- Would like an understanding what a system of system is, what it is supposed to do, and how well it is supposed to do it. Would like an ORD for system of systems.

- Given set of systems, what capability does each provide and what do they need from other systems. And if appropriate what do they need from a network? This gives you a way of assessing who is doing what. Block 3 has 250 tasks-you can allocate those tasks to the sys that the arch performs. Now you have the interface question...

- C4ISP: ISP for the future. How do we all fit against this? We don't have this...

- How mature is the Army in terms of its processes? Army needs an enterprise wide perspective-portfolio of its projects (programs)

- Wherever you say Army... consider you might say DoD and think multi national.

- Need a methodology to support architecture development. They think they have this but they are still looking at a system view. There is nothing to support this from a system of systems view. Who owns this? Who can make this happen?

\section{Programmatic}

- Requirements belong to the joint community. Then planning, programming, budgeting and execution-all go off to the services. The problem is there is no single belly button. Designed to promote 5 separate services and system specific acquisition.

- How you buy a truck is different from how you deliver software.

\section{Operational}

- TRADOC family of people responsible for defining the req. This document justifies the existence of every program.

- Organization structure impedes coordination of requirements, later it impedes the development of the system (because they follow the requirements). Interoperability is determined after the fact, band aided in. 
- This is all done at end instead of at the beginning.... What do we want to have on the battlefield in 2010? How are we going to operate? What do we think the threads are? Build the threads in conjunction with the warfighter. Whereas now, we build systems and then try to glue things together (certification). (It's the wrong place for systems to come together on the test floor.)

- If mission threads were worked in advance, if TRADOC got together and went through these threads.... Then the acquisition community comes in with those threads and says this system does this, this system does this... and you give that info to the contactor...

- There are multiple different definitions of mission threads. FCS doesn't have mission threads it has integrated processes. Is there a preferred language to use? Operational views and system views. The Message to Send: Software blocking and test floor have found operational mission threads to be useful, but.... (there seems to be limitations here, or this is insufficient)

- Need requirements up front, what systems are involved, then base funding on this prioritization. It's the 30 year old problem - that separates function from the data.

- Definition and management of the network itself in the comms

- Can’t prioritize functionality effectively

- Now, things are built on gaps - on fixing holes. Throwing money at a app vs throwing money at a solution

- Think too stovepiped, also solving today's problem in today's environment

- Focused on short term. Should Mandate planning out to 5 years.

- Rewards are wrong

- Doctrine inhibiting future force? Yes, but it's never going to happen more than 3-5 years for now.

- Do we have the right people? Do we need more people? We need as different focus. Do people need to stay in place longer? Yes -5 years.

\section{Uncategorized}

- Lack of sharing of context information at messages; better data and user access.

- Lack of standards and not implementing standards in a specified way

- Procurement versus development lifecycle model causes interoperability problems for when functions implemented

- Managing expectations of (Government, contractor, Congress, users) to limit appetite. Rush to add functions

- Not organized to build a SOS. Lack of understanding requirements, \$\$ allocation, interaction, test.

- Synchronization with joint systems with respect to budget, \$

- We don’t plan to be interoperable 
- Overoptimistic schedule crunch

- Acquisition process is not designed for a SOS

- Acquisition process is linear but you really want evolution and there is a mismatch

- Development and enforcement of a common data model(s) does not work

- Need single management approach (overall), not FCS, not blocking. Lack of integrated approach. Need more emphasis on blocking.

- We fail to communicate (jargon)

- Battlefield comms cannot keep up with user appetite

- We don't hear each other

- Proliferation of requirements

- Need rewards/incentive for SOS at all

- Loss of in-house technical capabilities by Government

- Inefficient application in deciding how resources should be allocated

- Contracting of pieces of equipment is separate from blocking (+USF, +resetting), + operational need

- Migration plan must be at the appropriate higher level, not bottom-up focus. Network not radios, fielding

- USF was fine until modularity and resetting

- Focus on material solutions. Need robust solution-finding process that considers DOTMLPF

- $\quad$ Need process for measuring operational benefit of proposed interoperability solutions. E.g., cost/benefits analysis 


\section{Appendix C: Acronyms}

ACP

AOA

ASA/ALT

ASP

ATEC

AUTL

BTR

C4ISP

CCA

DOD, DoD

DOTMLPF

FAR

FCS

IRAD

ISIS

JCIDS

JTRS

LSI
Army Campaign Plan

Analysis of Alternatives

Assistant Secretary of the Army For Acquisition, Logistics, and Technology

Acquisition Support Program

Army Test and Evaluation Command

Army Universal Task List

Below Threshold Reprogramming

Command, Control, Computers, and Communications Integrated Support Plan

Clinger Cohen Act (formerly the Information Technology Management Reform Act (ITMRA) of 1995)

Department of Defense

Doctrine, Organizations, Training, Materiel, Leader Development, Personnel and Facilities

Federal Acquisition Regulations

Future Combat System

Independent Research and Development

Integration Of Software Intensive Systems

Joint Capability Integration and Development System

Joint Tactical Radio System

Lead System Integrator 
ORD

PMO

SEI

SEMP

SETD

SOS, SoS

SOSI

SSEI

TRADOC

USF
Operation Requirements Document (replaced by the ICD - Initial Capabilities Document)

Program Management Office

Software Engineering Institute

Systems Engineering Management Plan

System Engineering and Technical Direction

System of Systems

System-Of-Systems Interoperability

System-of-Systems Engineering and Integration

Training And Doctrine Command

Unit Set Fielding 


\section{References}

URLs are valid as of the publication date of this document.

[Meyers 05] Meyers, C.; Monarch, I.; Levine, L.; \& Smith, J. Including Interoperability in the Acquisition Process (CMU/SEI-2005-TR004) Pittsburgh, PA: Software Engineering Institute, Carnegie Mellon University, 2005.

http://www.sei.cmu.edu/publications/documents/05.reports /05tr004.html.

[Morris 04] Morris, E.; Levine, L.; Meyers, C.; Place, P.; \& Plakosh, D. System of Systems Interoperability (SOSI): Final Report (CMU/SEI-2004TR-004). Pittsburgh, PA: Software Engineering Institute, Carnegie Mellon University, 2004.

http://www.sei.cmu.edu/publications/documents/04.reports /04tr004.html. 


\begin{tabular}{|c|c|c|c|c|}
\hline \multicolumn{3}{|c|}{ REPORT DOCUMENTATION PAGE } & \multicolumn{2}{|c|}{$\begin{array}{l}\text { Form Approved } \\
\text { OMB No. 0704-0188 }\end{array}$} \\
\hline \multicolumn{5}{|c|}{ 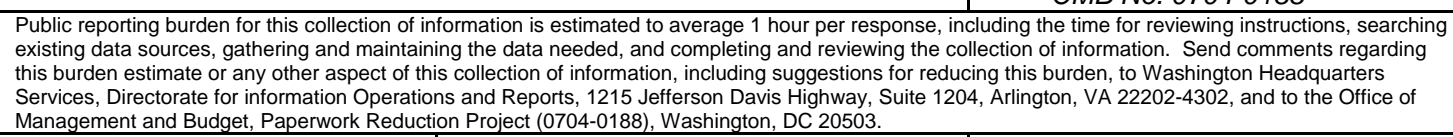 } \\
\hline $\begin{array}{l}\text { AGENCY USE ONLY } \\
\text { (Leave Blank) }\end{array}$ & \multicolumn{2}{|c|}{$\begin{array}{ll}\text { 2. } & \text { REPORT DATE } \\
\text { September } 2005\end{array}$} & \multicolumn{2}{|c|}{$\begin{array}{l}\text { 3. } \\
\text { REPORT TYPE AND DATES COVERED } \\
\text { Final }\end{array}$} \\
\hline \multicolumn{3}{|c|}{$\begin{array}{l}\text { TITLE AND SUBTITLE } \\
\text { Exploring Programmatic Interoperability: Army Future Force } \\
\text { Workshop }\end{array}$} & \multicolumn{2}{|c|}{$\begin{array}{ll}5 . & \text { FUNDING NUMBERS } \\
& \text { FA8721-05-C-0003 }\end{array}$} \\
\hline \multicolumn{5}{|c|}{$\begin{array}{ll}\text { 6. } & \text { AUTHOR(s) } \\
\text { James D. Smith II, B. Craig Meyers }\end{array}$} \\
\hline \multicolumn{3}{|c|}{$\begin{array}{l}\text { 7. PERFORMING ORGANIZATION NAME(S) AND ADDRESS(ES) } \\
\text { Software Engineering Institute } \\
\text { Carnegie Mellon University } \\
\text { Pittsburgh, PA } 15213\end{array}$} & \multicolumn{2}{|c|}{$\begin{array}{ll}8 . & \text { PERFORMING ORGANIZATION } \\
\text { REPORT NUMBER } \\
\text { CMU/SEI-2005-TN-042 }\end{array}$} \\
\hline \multicolumn{3}{|c|}{$\begin{array}{l}\text { 9. SPONSORING/MONITORING AGENCY NAME(S) AND ADDRESS(ES) } \\
\text { HQ ESC/XPK } \\
5 \text { Eglin Street } \\
\text { Hanscom AFB, MA 01731-2116 }\end{array}$} & \multicolumn{2}{|c|}{$\begin{array}{l}\text { 10. SPONSORING/MONITORING AGENCY } \\
\text { REPORT NUMBER }\end{array}$} \\
\hline \multicolumn{5}{|c|}{ 11. SUPPLEMENTARY NOTES } \\
\hline \multicolumn{3}{|c|}{$\begin{array}{l}\text { 12A DISTRIBUTION/AVAILABILITY STATEMENT } \\
\text { Unclassified/Unlimited, DTIC, NTIS }\end{array}$} & \multicolumn{2}{|c|}{ 12B DISTRIBUTION CODE } \\
\hline \multicolumn{5}{|c|}{$\begin{array}{l}\text { This report documents the proceedings of the Future Force Workshop held at the Software Engineering } \\
\text { Institute on October 13-14, 2004. It describes the background and motivation for the workshop, provides a } \\
\text { brief overview of the workshop activities, and highlights the key observations and conclusions obtained } \\
\text { through the course of the workshop and post-workshop analyses. In addition, a set of recommended next } \\
\text { steps is described. }\end{array}$} \\
\hline \multicolumn{3}{|c|}{$\begin{array}{l}\text { 14. SUBJECT TERMS } \\
\text { programmatic interoperability, decomposition, workshop, Future } \\
\text { Force, Army Future Force Workshop }\end{array}$} & \multicolumn{2}{|c|}{$\begin{array}{l}\text { 15. NUMBER OF PAGES } \\
53\end{array}$} \\
\hline \multicolumn{5}{|l|}{ 16. PRICE CODE } \\
\hline $\begin{array}{l}\text { 17. SECURITY CLASSIFICATION } \\
\text { OF REPORT } \\
\text { Unclassified }\end{array}$ & $\begin{array}{l}\text { 18. SECURITY CLASSIFICATION OF } \\
\text { THIS PAGE } \\
\text { Unclassified }\end{array}$ & $\begin{array}{l}\text { 19. SECURITY CLAS } \\
\text { ABSTRACT } \\
\text { Unclassified }\end{array}$ & SIFICATION OF & $\begin{array}{l}\text { 20. LIMITATION OF ABSTRACT } \\
\text { UL }\end{array}$ \\
\hline
\end{tabular}

